\title{
Comparison of Standard Open Wound Care and Vacuum-assisted Closure Therapy in Fournier's Gangrene
}

\section{Fornier Gangreni Tedavisinde Standart Açık Yara Pansumanı ve Vakum Yardımlı Kapamanın Karşılaştırılması}

\author{
(D) Zülfikar Ulaş Bali2, (D) Caner Buğra Akdeniz¹, (D) Talha Müezzinoğlu11, (D) Oktay Üçer1, (D) Eray Kara3 \\ ${ }^{1}$ Manisa Celal Bayar University Faculty of Medicine, Department of Urology, Manisa, Turkiye \\ 2 Manisa Celal Bayar University Faculty of Medicine, Department of Plastic and Reconstruction Surgery, Manisa, Turkiye \\ 3 Manisa Celal Bayar University Faculty of Medicine, Department of Surgery, Manisa, Turkiye
}

What's known on the subject? and What does the study add?

The effect of VAC in therapy of Fournier's gangrene.

\begin{abstract}
Objective: Management of Fournier's gangrene (FG) includes large wound debridement, broad-spectrum antibiotic, wound care and re-debridement if necessary. The aim of our study was to compare standard open wound care and vacuum-assisted closure (VAC) therapy in patients with FG.

Materials and Methods: Thirty-three patients (29 males and 4 females) who underwent surgery for FG were enrolled in the present study. The data was evaluated retrospectively. The patients were divided into two groups according to wound care after large wound debridement. Standard open wound care with antibiotic pomade was performed twice a day in 14 patients and VAC therapy was performed every 48-72 hours in 17 patients. The data of the two groups were compared.

Results: Twenty-three (69.7\%) patients had Diabetes Mellitus and 20 patients (60\%) had poor hygiene. The re-debridement rate in patients who received standard open wound care was statistically higher than in those who underwent VAC therapy $(p=0.016)$. There were no statistically significant differences in mortality rate, length of hospital stay and need for reconstruction between the groups. When the data were analyzed, no statistically significant difference was found in FG Severity index score, length of hospital stay and mortality rate. However, the relationship between mortality rate and location of lesion was statistically significant ( $p=0.03)$. Four patients died, 3 (75\%) due to wide necrotizing fasciitis extending to the abdominal wall.

Conclusion: The present study showed that the technique used for wound care did not influence mortality, need for reconstruction and length of hospital stay. The only advantage of VAC therapy was decreased re-debridement rate in patients with FG.
\end{abstract}

Keywords: Fournier's gangrene, Wound care, Vacuum-assisted closure therapy, VAC

Öz

Amaç: Fornier gangreninin tedavisi, agresif yara debridmanı, geniş spektrumlu antibiyotik kullanımı, yara bakımı ve gerekirse tekrar debridman gerektirir. Çalışmamızın amacı Fornier gangrenli hastaların tedavisinde klasik yara bakımının ve vakum yardımlı kapama malzemelerinin karşılaştırılmasıdır.

Gereç ve Yöntem: Çalışmaya Fornier gangreni nedeniyle cerrahi yapılan otuz üç hasta (29 erkek ve 4 kadın) dahil edildi. Veriler retrospektif olarak değerlendirildi. Hataların 23 tanesi $(\% 69,7)$ Diyabet hastalığı vardı ve 20 hastada $(\% 60)$ kötü hijyen mevcuttu. Hastalar debridman sonrası yara bakımına göre 2 gruba ayırıldı. On dört hastaya antibiyotikli pomad ile günde 2 kez standart yara pansumanı yapıldı. On yedi hasta, 48-72 saatte bir değişen VAC tedavisi ile takip edildi. İki grubun verileri karşılaştırıldı.

Bulgular: Hastaların 23 tanesi $(\% 69,7)$ Diyabet hastalığı vardı ve 20 hastada (\%60) kötü hijyen mevcuttu. Klasik pansuman ile takip edilen hastalarda tekrar debridman oranları VAC ile takip edilen hastalara göre istatistiksel olarak fazlaydı $(p=0,016)$. Mortalite oranları, hastanede yatış süreleri ve

Correspondence: Oktay Üçer MD, Manisa Celal Bayar University, Faculty of Medicine, Department of Urology, Manisa, Turkiye

Phone: +90 5052114618 E-mail: uceroktay@yahoo.com ORCID-ID: orcid.org/0000-0001-7912-0408

Received: 20.09.2019 Accepted: 15.10.2019

Cite this article as: Bali ZU, Akdeniz CB, Müezzinoğlu T, Üçer O, Kara E. Comparison of Standard Open Wound Care and Vacuum-assisted Closure Therapy in Fournier's Gangrene J Urol Surg 2020;7(1):42-45

๑Copyright 2020 by the Association of Urological Surgery / Journal of Urological Surgery published by Galenos Publishing House. 
rekonstrüksiyon ihtiyaçlarında anlamlı farklılık saptanmadı. Veriler analiz edildiğinde FG Şiddeti indeksi skorlarında, hastanede yatış süresinde ve mortalite oranlarında istatistiksel bir fark bulunmadı. Ancak mortalite oranı ile lezyon lokalizasyonu arasındaki ilişki istatistiksel olarak anlamlıydı $(p=0,03)$. Mortalitenin görüldüğü 4 hastanın 3'ü $(\% 75)$ abdominal duvara yayılan geniş nekrotizan fasiit nedeniyle öldü.

Sonuç: Bu çalışma, yara bakımı tekniğinin mortalite, rekonstrüksiyon ihtiyacı ve hastanede yatış süresini etkilemediğini göstermiştir. VAC tedavisinin tek avantajı yeniden debridman oranındaki azalmadır.

Anahtar Kelimeler: Fornier gangreni, Yara bakımı, Vakum yardımlı kapama, VAC

\section{Introduction}

Fournier's gangrene $(\mathrm{FG})$, a rare necrotizing fasciitis of the genital, perineal and perianal regions, was first described in 1764 and then named by Jean-Alfred Fournier in $1883(1,2)$. It is more common in developing countries and males are affected 10 -fold more commonly than females (3). FG is a urological emergency and requires immediate hospitalization. Early diagnosis is very important to decrease the rate of mortality related to the disease. Treatment of FG includes urgent large surgical debridement, broad-spectrum antibiotic therapy, wound care therapy and re-debridement if necessary. In spite of this aggressive management, mortality rate of the disease has been reported to be $7.5-45 \%$ (4).

Wound care therapy after radical surgical debridement is an important part of treatment. Different approaches, including standard open wound therapy, vacuum-assisted closure (VAC) therapy and negative pressure wound therapy (NPWT), have been used for wound care. VAC therapy and NPWT have recently become popular in the postoperative management of FG. Different approaches to open wound care, such as sterile dressing, Dakin's solution and topical honey, have been investigated. Recently, effectiveness of VAC and NPWT in postoperative treatment of FG has been evaluated (5). The aim of our study was to compare the effects of VAC and open standard wound care on wound healing after radical debridement.

\section{Materials and Methods}

A total thirty-three patients (29 males and 4 females) with $\mathrm{FG}$, who underwent radical surgical debridement in the departments of general surgery, urology and plastic and reconstructive surgery in Manisa Celal Bayar University between January 2002 and May 2018, were enrolled in the present study. Data on medical history, symptoms, physical examination findings, such as size and location of the lesion, were analyzed retrospectively. The data on laboratory tests, surgical debridement and postoperative wound care were evaluated. The diagnosis of FG was based on the medical history and clinical symptoms including tenderness and/or erythema of the perianal, perineal or genital region, skin edema, fluctuation and/or crepitation of the subcutaneous tissue, gangrene or necrosis, purulent discharge and fever. Patients who had no necrotizing fasciitis and had only limited perineal or scrotal abscess were excluded from the study. Fournier's Gangrene Severity index (FGSI) was calculated to measure the severity of FG (6). In the FGSI, 9 parameters, including temperature, heart and respiratory rates, white blood cell count, hematocrit, serum sodium, potassium, creatinine and bicarbonate levels, are scored (the degree of deviation from normal is graded from 0 to 4). The patients in the study were divided into two groups according to the management of wound care (VAC therapy and open standard wound care) after surgical debridement. Standard open wound care was performed with antibiotic pomade twice a day. VAC therapy was performed once every $48-72$ hours. The data of the groups were analyzed statistically. The local ethics committee approved the study protocol.

\section{Statistical Analysis}

Statistical analysis was carried out using the Statistical Package for the Social Sciences for Windows, version 18.0 (SPSS, IL, USA). Differences in variables between the groups were analyzed using the chi-square and Mann-Whitney $U$ tests. A $p$ value of less than 0.05 was considered statistically significant.

\section{Results}

In the present study, the mean age of the participants was $56.21 \pm 14.02$ years. Twenty three patients (69.7\%) had Diabetes Mellitus (DM) and 8 (24.2\%) had hypertension (HT). The mean length of hospital stay (day), FGSI score and debridement area $\left(\mathrm{cm}^{2}\right)$ were $23.87 \pm 14.25,5.09 \pm 3.20$ and $119.18 \pm 103.22$, respectively. Twelve patients (36.4\%) underwent reconstruction surgery after debridement and wound care therapy. Four patients $(12.1 \%)$ died during hospitalization. When mortality rates according to extension of lesions were evaluated, the mortality rate in patients who had necrotizing fasciitis extending to the abdominal wall was statistically significant higher $(p<0.05)$. The mortality rates in patients with abdominal wall, perineal and scrotal and/or penile extension were 30\% (3/10), 14.3\% (1/7) and $0 \%(0 / 16)$, respectively. There was no statistically significant difference in mean age, FGSI score, debrided area and rate of DM and $\mathrm{HT}$ between VAC and open standard therapy groups (Table 1). Although the mortality rate, length of hospital stay and need for reconstruction were similar between the two groups, the 
rate of re-debridement in VAC group was statistically lower than in open standard wound care group $(p<0.5)$ (Table 2).

\begin{tabular}{|c|c|c|c|}
\hline & $\begin{array}{l}\text { VAC therapy } \\
(n=17)\end{array}$ & $\begin{array}{l}\text { Open standard } \\
\text { wound care } \\
(n=16)\end{array}$ & $\mathbf{p}$ \\
\hline Age (years) & $59.52 \pm 12.30$ & $52.68 \pm 14.88$ & 0.15 \\
\hline FGSI score & $4.70 \pm 3.05$ & $5.50 \pm 3.40$ & 0.42 \\
\hline Debrided area $\left(\mathrm{cm}^{2}\right)$ & $135.11 \pm 112.49$ & $102.25 \pm 9$ & 0.48 \\
\hline DM & $13 / 17(76.4 \%)$ & $10 / 16(62.5 \%)$ & 0.46 \\
\hline HT & $3 / 17(17.6 \%)$ & $5 / 16(31.2)$ & 0.43 \\
\hline
\end{tabular}

Table 2. Comparison of mortality rates, hospitalization times, needs for re-debridement and reconstruction in vacuumassisted closure therapy and open standard wound care

\begin{tabular}{|l|l|l|l|}
\hline & $\begin{array}{l}\text { VAC therapy } \\
(\mathbf{n}=\mathbf{1 7})\end{array}$ & $\begin{array}{l}\text { Open standard } \\
\text { wound care } \\
(\mathbf{n = 1 6 )}\end{array}$ & $\mathbf{p}$ \\
\hline $\begin{array}{l}\text { Mortality rate during } \\
\text { hospitalization }\end{array}$ & $1 / 17(5.9 \%)$ & $3 / 16(18.8 \%)$ & 0.35 \\
\hline $\begin{array}{l}\text { Hospitalization times } \\
\text { (days) }\end{array}$ & $23.11 \pm 13.13$ & $24.68 \pm 15.74$ & 0.78 \\
\hline Re-debridement rate & $4 / 17(23.5 \%)$ & $11 / 16(68.7)$ & $0.001^{*}$ \\
\hline Reconstruction rate & $8 / 17(47.1 \%)$ & $4 / 16(33.3 \%)$ & 0.17 \\
\hline VAC: Vacuum-assisted closure, ${ }^{*}$ Statistically significant difference (chi-square test) \\
\hline
\end{tabular}

\section{Discussion}

The treatment of FG includes radical surgical debridement of necrotized tissue, broad-spectrum antibiotics and hemodynamic support with fluids (7). The other important principle in the management of $F G$ is wound care after initial radical debridement $(5,8)$. Open debrided wounds are generally managed with sterile dressing and povidone iodine or antibiotic. Some studies have compared various open wound approaches such as with povidone iodine, Dakin's solution and topical honey and noticed both advantages and disadvantages $(9,10)$. Recently, NPWT and VAC therapy have become popular treatment options for wound care in FG. However, there have been a few studies about these approaches for postoperative therapy of FG in the literature. VAC therapy for the postoperative treatment of FG was first reported by Weinfeld et al. (11) in 2005. They used VAC therapy for the management of debrided wounds in three patients who had FG and reported that all patients achieved successful genital wound coverage. The results of the other two studies that investigated the outcomes of VAC therapy for postoperative management of
FG were similar to the results of the first study $(12,13)$. Assenza et al. (12) investigated six male cases of FG who had DM and suggested that VAC was a time-saving method. The results of their study showed that VAC decreased length of hospital stay, patient discomfort and number of medications and improved significantly quality of life. Similar to this study, Cuccia et al. (13) evaluated the outcomes of VAC for postoperative wound therapy in six patients who had very extensive FG (the mean FGSI was 10.5). They reported that VAC therapy was effective in cleaning and preparing the wounds, and decreased the length of hospital stay and patient discomfort. However, the two important limitations of these two studies were small sample size and absence of control group. Our study compared VAC and open standard wound therapy, and had larger study populations than in their studies. Our results showed that the length hospital stay in patients who underwent VAC and open standard wound therapy were statistically similar.

According to the best of our knowledge, there have been two studies $(14,15)$ that compared VAC and open standard wound therapy for postoperative management of FG. Ozturk et al. (14) compared VAC $(n=5)$ and conventional therapy $(n=5)$ for the management of $F G$ following initial debridement in a small number of patients. The results of their study showed that VAC and conventional therapies were equally effective in healing the wounds and the total costs of them were statistically similar. The results also indicated that with the use of VAC, patients had less pain and dressing changes, and greater mobility. They found that hands-on treatment time was reduced for physicians using VAC. In conclusion, they suggested that VAC therapy was an economical and effective option for wound therapy after debridement. They also noticed that the patients and physicians were more satisfied with VAC therapy than with conventional wound therapy. We did not investigate physicians' satisfaction but the hands-on treatment time in VAC group was shorter than in open standard group, because VAC and open standard wound therapy were performed once every 2-3 days and twice a day, respectively. Although the length of hospital stay and need for reconstruction were statistically similar between the groups, re-debridement rate in VAC group was significantly lower than in open standard group. Czymek et al. (15) evaluated 35 patients with FG. Nineteen patients underwent VAC therapy and other 16 patients were managed with antiseptic dressing after debridement. They noticed that VAC therapy was associated with longer hospital stay and lower mortality. They stated that a partial explanation was that some patients with severe sepsis died in the first 3 days and could not undergo VAC therapy. In our study, there was no statistically significant difference in mean age, FGSI score, debrided area, and DM and HT rates between the two groups (VAC and open standard). Two groups with similar features in comorbidity and FG were compared in our study. Therefore, the outcomes of our study are more valuable than 
that of above mentioned studies. We found that length hospital stay, mortality rate and reconstruction rate were statistically similar between the groups. The results of our study showed that VAC and conservative open therapy in the postoperative treatment of $F G$ had similar effectiveness but the advantage of VAC therapy was less needs for re-debridement. The limitations of the present study were small and retrospective design. So we suggest that further prospective studies comparing VAC and standard open wound therapy in larger study groups are warranted.

\section{Conclusion}

The results of our study indicated that length of hospital stay and reconstruction rate were similar between VAC and open standard wound therapy for postoperative treatment of FG. Moreover, the most important advantage of VAC therapy was decreasing re-debridement rates. Lower re-debridement rate and dressing frequency in VAC therapy might decrease hands-on treatment time and increase physician satisfaction. Therefore, we think that VAC therapy is more comfortable than open standard wound therapy for patients and physicians.

\section{Ethics}

Ethics Committee Approval: The local ethics committee approved the study (protocol no: 03.02.2020-68).

Informed Consent: Retrospective study.

Peer-review: Internally peer-reviewed.

\section{Authorship Contributions}

Concept: Z.U.B., O.U., Design: C.B.A., T.M., Data Collection or Processing: E.K., Analysis or Interpretation: O.U., Literature Search: Z.U.B., Writing: Z.U.B., C.B.A., O.U.

Conflict of Interest: No conflict of interest was declared by the authors.

Financial Disclosure: The authors declared that this study received no financial support.

\section{References}

1. Baurienne H. Sur une plaie contuse qui s'est terminee par la sphacele de la scrotum. J Med Chir Pharm 1764;20:251-256.

2. Fournier JA. Gangrene foudroyante de la verge. Semin Med 1883;3:345348.

3. Eke N. Fournier gangrene: review of 1723 cases. Br J Surg 2000;87:718-728.

4. Lin TY, Ou CH, Tzai TS, Tong YC, Chang CC, Cheng HL, Yang WH, Lin YM. Validation and simplification of Fournier's gangrene severity index. Int J Urol 2014;21:696-701.

5. Chennamsetty A, Khourdaji I, Burks F, Killinger KA. Contemporary diagnosis and management of Fournier's gangrene. Ther Adv Urol 2015;7:203-215.

6. Laor $\mathrm{E}$, Palmer LS, Tolia BM, Reid RE, Winter HI. Outcome prediction in patients with Fournier's gangrene. J Urol 1995;154:89-92.

7. Akilov 0, Pompeo A, Sehrt D, Bowlin P, Molina WR, Kim FJ. Early scrotal approximation after hemiscrotectomy in patients with Fournier's gangrene prevents scrotal reconstruction with skin graft. Can Urol Assoc J 2013;7:481485.

8. Kara E, Muezzinoglu T, Temeltas G, Dinçer L, Kaya Y, Sakarya A, Coskun T. Evaluation of risk factors and severity of a life threatening surgical emergency: Fournier's gangrene (a report of 15 cases). Acta Chir Belg 2009;19:191-197.

9. Altunoluk B, Resim S, Efe E, Eren M, Benlioglu C, Kankilic N, Baykan H. Fournier's Gangrene: Conventional Dressings versus Dressings with Dakin's Solution. ISRN Urol 2012;2012:762340.

10. Tahmaz L, Erdemir F, Kibar Y, Cosar A, Yalcýn 0. Fournier's gangrene: report of thirty-three cases and a review of the literature. Int J Urol 2006;13:960967.

11. Weinfeld AB, Kelley P, Yuksel E, Tiwari P, Hsu P, Choo J, Hollier LH. Circumferential negative-pressure dressing (VAC) to bolster skin grafts in the reconstruction of the penile shaft and scrotum. Ann Plast Surg 2005;54:178-183.

12. Assenza M, Cozza V, Sacco E, Clementi I, Tarantino B, Passafiume F, Valesini L, Bartolucci P, Modini C. VAC (Vacuum Assisted Closure) treatment in Fournier's gangrene: personal experience and literature review. Clin Ter 2011;162:1-5.

13. Cuccia G, Mucciardi G, Morgia G, Stagno d'Alcontres F, Gali A, Cotrufo $\mathrm{S}$, Romeo $\mathrm{M}$, Magno $\mathrm{C}$. Vacuum-assisted closure for the treatment of Fournier's gangrene. Urol Int 2009;82:426-431.

14. Ozturk E, Ozguc H, Yilmazlar T. The use of vacuum assisted closure therapy in the management of Fournier's gangrene. Am J Surg 2009;197:660-665

15. Czymek R, Schmidt A, Eckmann C, Bouchard R, Wulff B, Laubert T, Limmer $\mathrm{S}$, Bruch HP, Kujath P. Fournier's gangrene: vacuum-assisted closure versus conventional dressings. Am J Surg 2009;197:168-176. 